\title{
The complexity of maladaptation strategies to disasters: The case of Muzarabani, Zimbabwe
}

\author{
Authors: \\ Siduduziwe Ncube-Phiri ${ }^{1}$ \\ Chipo Mudavanhu ${ }^{1}$ \\ Blessing Mucherera ${ }^{1}$

\section{Affiliations:} \\ ${ }^{1}$ Department of Geography, \\ Bindura University of Science \\ Education, Zimbabwe \\ Correspondence to: \\ Siduduziwe Ncube-Phiri \\ Email: \\ sduphiri@gmail.com \\ Postal address: \\ Private Bag 1020, Bindura, \\ Zimbabwe \\ Dates: \\ Received: 02 July 2014 \\ Accepted: 03 Oct. 2014 \\ Published: 28 Nov. 2014 \\ How to cite this article: \\ Ncube-Phiri, S., Mudavanhu, \\ C. \& Mucherera, B., \\ 2014, 'The complexity of \\ maladaptation strategies \\ to disasters: The case of \\ Muzarabani, Zimbabwe', \\ Jàmbá: Journal of Disaster \\ Risk Studies 6(1), Art. \#145, \\ 11 pages. http://dx.doi.org/ \\ 10.4102/jamba.v6i1.145

\section{Copyright:} \\ (C) 2014. The Authors. \\ Licensee: AOSIS \\ OpenJournals. This work is \\ licensed under the Creative \\ Commons Attribution \\ License.
}

\section{Read online:}

Scan this QR code with your smart phone or mobile device to read online.
Over the past decade disasters have increased both in complexity and multiplicity, worsening the plight of vulnerable communities the world over. Many communities have devised coping mechanisms to mitigate the impact, but communities such as Muzarabani in Zimbabwe remain susceptible to disasters. This article seeks to analyse whether the coping measures applied make the communities safe from or vulnerable to disasters. Information was obtained through interviews, questionnaires and observations from four villages in Chadereka in the Muzarabani district. The results of this study indicated that households, government and non-governmental organisations have come up with different mitigation strategies, such as growing crops along river beds, livestock production, raised granaries and doorsteps, flood evacuation shelters and other emergency services. Research revealed that although viable, some of the strategies increased the community's vulnerability. This article therefore recommends sustainable utilisation of resources, and collaborative efforts to address the root causes, dynamic pressures and unsafe conditions in order to reduce the vulnerability of poor communities to natural disasters.

\section{Introduction}

This article analyses the progression of the Muzarabani community towards vulnerability to hazards such as floods, drought and diseases inherent in that community, and how prevailing conditions and existing structures and activities increase susceptibility of this community to disasters. It proposes measures that can help the community to progress toward safety.

The question of how coping mechanisms can lead to vulnerability is central to this article, in the sense that existing structures and coping mechanisms in Muzarabani community create unsafe conditions, exacerbating vulnerability to disasters. This question is addressed by analysing how maladaptation strategies employed in Chadereka lead to progression towards disasters, using the pressure and release (PAR) model. Hansford, Dellor and MacPherson (2007) note that the PAR model helps us understand and analyse the complexity of community vulnerabilities.

Wisner et al. (2004) view vulnerability as rooted in social processes and underlying causes which may ultimately be quite remote from the disaster event itself. They argue that vulnerability involves a combination of these factors to determine the level to which lives, livelihood and property are subjected to risk by a discrete and unidentifiable event. The severe impact of floods in Chadereka Ward 1 is a result of maladaptation strategies such as deforestation, settlement and cultivation on the flood plain, determined by the root causes and dynamic pressure which has forced people to adopt these strategies. It is argued in this article that although viable, some of the measures are not sustainable; they tend to offer short-term solutions with longterm repercussions. To reduce disaster risk there is need to address those factors that cause disaster risk - and this entails reversing all of the components of the PAR model to progress to safety.

\section{Purpose of the study}

The main objective of this study was to examine the progression of the Muzarabani community towards vulnerability to hazards and to assess how the adopted coping strategies make the community more susceptible to disaster risks. Understanding vulnerability is crucial because of the many risks which households face; they often experience flood and drought hazards leading to income losses and property destruction.

The assumption was that flood disasters are often the result of some maladaptation strategies adopted by the community. This article offers the basis for self-study of their vulnerabilities and capabilities as they are defined through the PAR model. The study attempts to contribute to an understanding of household vulnerability to flood and drought hazards in the area, 
since an understanding of the sources of vulnerability is a precondition for successful disaster risk reduction policies and interventions.

The information obtained in this research should also stimulate the Government and non-governmental organisations (NGOs) to assist in building resilience in this community, as well as stimulating further research on vulnerability of communities to disaster in most rural areas.

\section{Research method and design \\ Study setting}

The study was carried out in Chadereka in the Muzarabani district. According to Madamombe (2004), geographically Muzarabani extends from $30^{\circ} 45^{\prime \prime} \mathrm{E}$ to $31^{\circ} 20^{\prime \prime} \mathrm{E}$ and $16^{\circ} 00^{\prime \prime} \mathrm{S}$ to $16^{\circ} 30^{\prime \prime} \mathrm{S}$. The district is located in Mashonaland Central Province in Zimbabwe. It is set along the flood plains of the Zambezi River, with Lake Kariba upstream and Lake Cabora Bassa downstream at the confluence of the Msengezi and Zambezi rivers about 400 ma.s.l. Chadereka Ward 1 is situated $60 \mathrm{~km}$ from Muzarabani Business Centre, and has a population of 6657 households (International Federation of Red Cross and Red Crescent Societies [IFRC] 2007).
Under normal circumstances and according to the local governance Rural District Council legislation, policies and regulations, a ward must constitute about 2000 households. This means that Chadereka is densely populated. The dense population is due to its fertile soils along the flood plains that support a wide variety of crop production. It was chosen as the study area because it is the worst affected by adverse environmental conditions, which include high temperatures, prevalence of epidemics, drought and flooding (Madamombe 2004).

Droughts have become a perennial problem, especially in the last decade, and floods have risen to unprecedented levels (Madamombe 2004). Prevalence of flooding in the area is as a result of increased flow due to the confluence of the Hoya and Nzou-Mvunda rivers (Figure 1).

The village is also affected by the backflow from Cabora Bassa and inflows from the Zambezi River. When Kariba Dam rises to a certain level, water is released to avoid dam failure. Most releases are done between December and February, causing the discharge into the Zambezi River to increase substantially. Further downstream the Cabora Bassa Dam levels continue to rise from inflows from Kariba Dam and Zambezi River feeder tributaries, which then leads to backflow, causing floods and loss of human life.

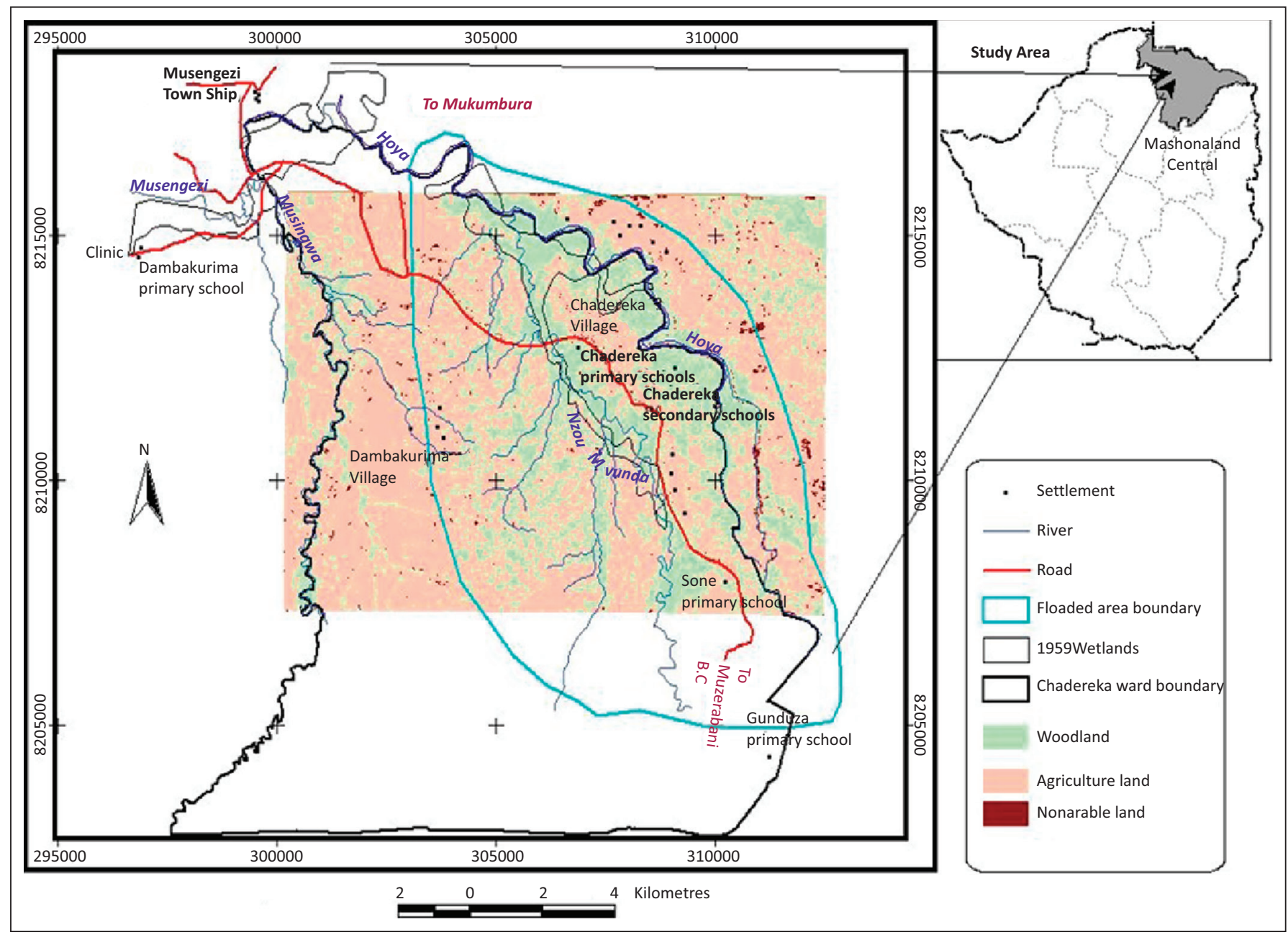

Source: Map drawn using GIS software by authors

FIGURE 1: The location of Chadereka village. 
For example, the cyclone-induced floods in the year 2000 claimed the lives of 700 people and left more than 500000 people homeless, causing over $\$ 1$ billion of infrastructural damage in Zimbabwe and Mozambique (Wamukonya \& Rukato 2001). During the December 2007 floods a total of 1000 households were affected, with 400 of them losing almost all of their belongings (IFRC 2007). The flooding also results in outbreaks of water-borne diseases such as malaria and cholera, further subjecting people to huge losses.

\section{Sampling}

Purposive non-probability sampling was used in this study. Purposive sampling is selecting a sample based upon the researcher's judgement and specific purpose rather than randomly (Teddlie \& Yu 2007). Selection of the study area was based on previous studies that declare it as the area most affected by climate-related hazards; hence there are also a lot of interventions going on there. Chadereka, Gunduza, Magarakata and Musengwa villages were chosen for the study.

The research was based on both secondary and primary data collected through key informant interviews, observations, focus group discussions (FGDs) and a household questionnaire survey. Multi-stage sampling was used to obtain 40 household heads from four villages for semistructured questionnaire interviews. An average of $22 \%$ representation was obtained from all of the villages (Table 1 ).

Multi-stage sampling, defined by Creswell and Plano (2011) as a process, whereby a sample is selected by using combinations of different sampling methods, was used in this research because it ensured adequate representation of all groups of interest. At the same time multi-stage sampling also maintains a high degree of external validity and minimises subjectivity in the sample selection (Robson 1993). Further sampling included 15 people in FGDs, and these represented the different socio-economic groups within the study area, mainly consisting of men, women, subsistence farmers, formally employed and unemployed community members. A semi-structured questionnaire was employed for individual household heads and elicited both qualitative and quantitative information. A participatory geographical information system was used to locate some of the mitigation structures that were later linked to a map. Personal observation was used to fill in gaps left by the other techniques used.

\section{Analytical framework}

The PAR model (Figure 2) by Wisner et al. (2004) traces the connections that link the impact of hazards on people to a set of political and social processes. The most distant are the root causes, which include economic, demographic and political processes which determine the access to and

TABLE 1: Distribution of semi-structured interview questionnaires.

\begin{tabular}{llll}
\hline Ward 1 villages & $\begin{array}{l}\text { Total number of } \\
\text { households }\end{array}$ & $\begin{array}{l}\text { Sample size } \\
\text { (households) }\end{array}$ & \% Representation \\
\hline Chadereka & 52 & 12 & 23.1 \\
Gunduza & 46 & 9 & 19.6 \\
Magarakata & 34 & 8 & 23.5 \\
Musengwa & 50 & 11 & 22.0 \\
\hline Total & $\mathbf{1 8 2}$ & $\mathbf{4 0}$ & $\mathbf{2 2 . 0}$ \\
\hline
\end{tabular}

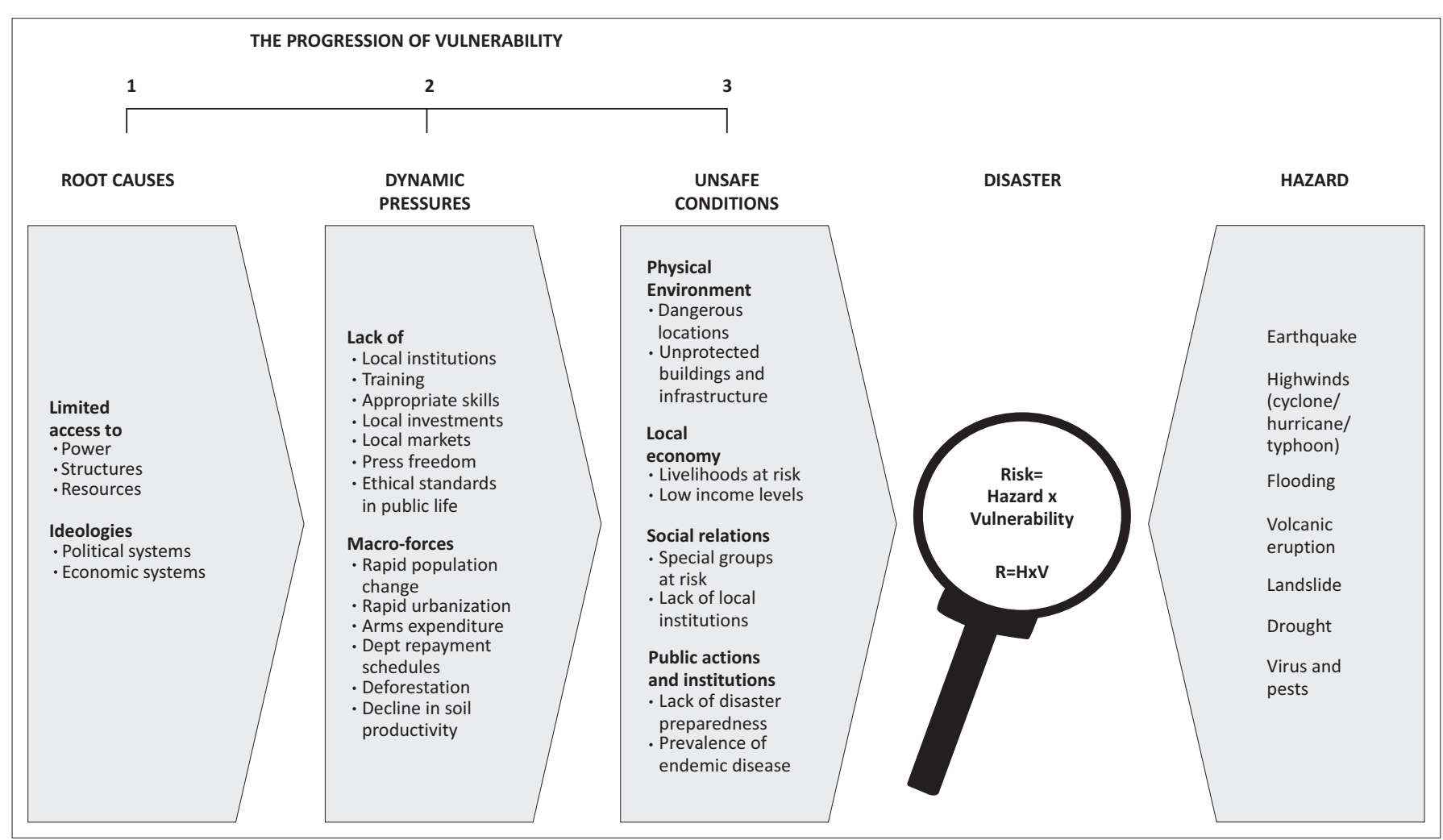

Source: Wisner, B., Blaikie, P., Cannon, T. \& Davis, I., 2004, At Risk: Natural Hazards, People's Vulnerability and Disasters, 2nd edn., Routledge, New York FIGURE 2: Pressure and release model. 
distribution of resources and power amongst people. The effects of root causes are translated by dynamic pressures into more visible unsafe conditions. When impacted upon by a hazard, the unsafe conditions result in loss of lives, property and livelihoods, and can cripple the community's capacity to respond effectively. The pressures built up on communities can be released by taking disaster risk reduction measures to reduce vulnerability along the causal chain (Wisner et al. 2004).

\section{Ethical considerations}

The research centred on people, and hence permission had to be sought from the local governance structures, that is the local councils and district administrators. The traditional local leadership and the university were also consulted, and permission was granted to carry out the research. It was also spelt out clearly on the research questionnaires and information gathered would strictly be used for academic purposes only. The respondents' confidentiality was assured and they were not forced to participate in the study.

\section{Trustworthiness}

The article contains information deemed to be true. A number of data collection tools were used to solicit data, and these included FGDs, key informant interviews and questionnaires. To ensure validity a representative sample was selected. Data collected from the community households and individuals were verified with the key informants, including the local councillors, traditional local leadership as well as NGO officers working in the area. Personal observation was also used to verify some of the information.

\section{Findings and discussion}

This section presents analysis and discusses the disaster coping strategies adopted in Muzarabani. It analyses and discusses underlying root causes, dynamic pressures and the unsafe conditions shaping coping measures, which in turn promote disaster risk accumulation. Respondents indicated how the situation is unfolding and leading to disaster.

\section{Major causes of disaster risk}

Several root causes of disaster risk were identified, including poverty, limited access to resources, cultural beliefs, precolonial ideology and a low educational level that promoted unsafe conditions. These are discussed below.

\section{Poverty as a root cause}

It was confirmed that the levels of poverty in the area are high, forcing many households to engage in subsistence farming known as mudzedze, that is growing maize crops along the flood plains as a means of earning a livelihood since the area is prone to drought. Poverty is understood in this study as the relative lack of or inability to attain services and household goods for the wellbeing of households (Baiyegunhi \& Fraser
2010). Information on socio-economic variables (Table 2), like the number of meals a day per household, number of dependants, type of occupation, social capital and credit constraints, were used to determine whether the community is in poverty or non-poor.

In Zimbabwe an average household consumes three meals a day, that is breakfast (comprising of tea and bread), lunch (comprising of cornmeal mush commonly known as sadza in Zimbabwe and relish such as green vegetables) and supper (comprising sadza with meat mixed with green vegetables). However, this study found that only $20 \%$ of respondents could afford three meals a day. The majority (74\%) eat only two meals, and $6 \%$ eat only one meal a day. It emerged from the interviews that those who eat two meals combine lunch and breakfast, whilst those who get one meal eat once in the evening in order to save food.

The fact that people are forced to cut meals in order to save food means the community is in absolute poverty. Similarly, information on their inability to get credit indicates that the majority of the population are living in abject poverty, as $95 \%$ of the respondents confirmed that they could not afford loans as they lacked collateral. This means that most of the population do not have property of significant monetary value, and hence can be classified as poor.

Moreover, most respondents being peasants who depend on rain-fed agriculture exhibited a lack of economic power, as they rely on subsistence farming as a livelihood in contrast to commercial farming which is also practised in Muzarabani. The majority of the households (87\%) are engaged in subsistence farming but do not own adequate resources to progress as farmers. This would lead one to infer that farming in this area is unlikely to provide any notable welfare benefits.

TABLE 2: Socio-economic characteristics of the respondents.

\begin{tabular}{llll}
\hline Socio-economic characteristics & Respondents & $n$ & $\mathbf{\%}$ \\
\hline Gender of household head & Male & 30 & 75 \\
& Female & 10 & 25 \\
Level of education & No schooling & 2 & 5 \\
& Primary level & 24 & 61 \\
& Secondary level & 11 & 27 \\
& Tertiary & 3 & 7 \\
Occupation & Subsistence farmers & 35 & 87 \\
Credit constraints status & Others & 5 & 13 \\
Social capital & Yes & 38 & 95 \\
& No & 2 & 5 \\
& 0 & 35 & 87 \\
& 1 & 5 & 13 \\
Number of dependants & 2 & 0 & 0 \\
& Above 2 & 0 & 0 \\
\hline Number of meals a day & 2 & 2 & 6 \\
& 4 & 8 & 19 \\
& 5 & 10 & 25 \\
& 2 & 20 & 50 \\
\hline
\end{tabular}


As advanced by Wisner et al. (2004), poverty is not synonymous with vulnerability; thus, during disaster occurrences the vulnerable can be driven into poverty whilst the poor are driven into abject poverty. It is the poor who suffer most during disasters; however, as the IFRC (2008) argues, a common feature in poor communities is that households always find ways of surviving in the midst of disasters. One would infer that as a result of poverty, the majority of the population place themselves at high risk of floods by settling and farming in a flood plain.

The study observed that this community often loses its crops, livestock and homesteads not because the area has received too much rainfall, but because the river system had a backflow. To substantiate this viewpoint one woman echoed a statement that:

'it will be folly for us to avoid farming mudzedze in fear of floods which may not come at all, we are happy here. Mudzedze is very lucrative, it cushions us from drought.' (Woman, villager, 63)

In addition, poverty weakens the community's ability to respond to drought and flood disaster risks effectively, and as such the wet, fertile flood plains along the Hoya and NzouMvunda rivers lure men and women in this community to engage in such risky agricultural activities, becoming highly vulnerable to floods. The United Nations Development Programme (1992) points out that lack of coping capacity makes communities and households vulnerable to natural disasters.

\section{Limited access to resources}

The differing levels of access to resources influence the community's ability to reduce the impact of drought and floods. Lack of access to resources such as financial and physical assets has a serious impact on the community's coping means, since it limits provision of support programmes through banks and other financial institutions. It emerged from the study that the poor are always on the receiving end of hardship, as the majority of the population fail to benefit from those programmes such as money lending and loan schemes aimed at empowering people, as they do not have the collateral security required by financial institutions. Table 2 indicates that $95 \%$ of the respondents could not benefit from such schemes due to their credit constraints; their limited access to property and financial resources was a major hindrance.

It was also evident from the research that this community had limited access to social capital; $87 \%$ of the respondents faced difficulties in coming up with local safety nets which could cushion them during times of hardship. In an interview one villager lamented about limited access to credit facilities and loans as a major concern amongst community members, as it undermines their capacity to procure farming equipment and drill boreholes in a bid to fight against drought.

When probed further as to whether they have attempted to take advantage of the Government loan scheme, respondents argued that it was not easy; moreover, one needed to come up with a project proposal - an insurmountable task for most of the local people as they could not write project proposals. The sentiments are supported by the results shown in Table 2, which indicate that most people have attained a low level of education. As a result, subsistence farming (growing mudzedze) was the only meaningful option available to earn a living.

\section{Cultural and precolonial ideologies}

According to Wisner et al. (2004) cultural and precolonial ideologies refer to pressures created or increased by political ideas, economic principles or cultural practices which encourage those in positions of power to marginalise and disempower those without access to these positions. In Chadereka Ward 1 these include economic imbalances created during the precolonial era and cultural beliefs. The lack of power of the community is linked to the political economy, where the preindependence social, economic and political climate bestowed all benefits to the white community as opposed to black people. Black people were relegated to poor-quality and small portions of land, whilst white people settled on large tracts of fertile land, (Zimbabwe National Statistics Agency 2013).

Key informant interviews revealed that the study area is habited by people who originally come from parts of Masvingo, Zaka and Bikita, amongst others, who came after 1980 since the area has good arable land with high temperatures suitable for tobacco farming, hence settling in harm's way (on a flood plain and in prevailing drought conditions). Wisner et al. (2004) argue that political ideologies engraved in the local population over centuries of historic processes can lead to significant deep-rooted vulnerability, such as in the case of Chadereka Ward 1.

It also emerged from interviews held with key informants that most people do not want to move away from the flood plain as they are culturally attached to the area. They feel they cannot move away from the flood plain, leaving behind their ancestral graves and homes. One interviewee exclaimed: 'We were born here and we will die here!' (Man, local councilor, 37). This indicates the high value placed on these ancestral homes and the respect given to the dead, regardless of the danger posed by the flood and drought hazards. Cultural rituals which needed to be performed at the graveyards would no longer be possible, and the families would drown in perpetual misfortune.

This study found that the International Organisation for Migration tried to relocate some people upland, just across Nzou-Mvunda River locally known as Magarakata, but still they returned to the risky areas, citing these cultural beliefs. The majority of the respondents indicated that although the area is at risk of flooding they are not willing to be relocated since they have the obligation to stay close to the graves of their dead relatives. Others insisted that their culture did not permit them to leave their inherited properties in the area and that they have the responsibility to protect and preserve them for future generations. This kind of belief tends to weaken efforts aimed at reducing the impact of the flood hazard such as resettlement. 


\section{Low educational level}

Findings indicated that the majority of people in this community have not attained a high level of education (Table 2); for instance, $61 \%$ attained primary level education, very low education by Zimbabwe's standards, whilst $5 \%$ noted that they had never attended school. Only $7 \%$ had gone up to tertiary level and $27 \%$ to secondary level. Suffice it to assume that the level of education affects the way in which information about drought and flood hazards is understood and perceived in this community. It means that community members are not able to link their agricultural practices to actions that increase the risk of flooding, for example, the stream bank cultivation prevalent in the area. This is due to limited knowledge. Walden, O'Reilly and Yetter (2007) hold a similar view that lack of knowledge about disaster risks still affects many as they engage in risky behaviours unaware of the consequences.

In addition, the fact that most people attained a low level of education means they cannot be formally employed, hence adoption of maladaption strategies like growing of mudzedze, which increases the high risk of flooding as a result of siltation.

The identified root causes are supported by Wisner et al. (2004), who propound that the most important root causes that give rise to vulnerability are economic, demographic and political processes since they affect the distribution of resources.

\section{Dynamic pressures}

The root causes discussed above were believed to be transforming into the dynamic pressures outlined below.

\section{Lack of modern information on flood and storm hazard risks}

The key informants interviewed indicated that the community relies on a number of sources of information, and that some of these give false warnings. These include the radio system at Chadereka Clinic, cell phone and word of mouth in addition to the mainstream media (radio and television); however, $80 \%$ of the respondents noted that they did not have radio or television sets. Although cell phones are now common in most rural communities, in Chadereka the network coverage is very poor, making it difficult to transmit messages. Besides the poor network system, most of the time cell phones will be turned off because they do not have the means to charge them.

From the five categories in Figure 3, only 25\% (5\% newspapers and $20 \%$ radio and television) of the respondents said they received early-warning information from public media; (29\%) said they get the messages from Chadereka Clinic, where there is a radio system, and $21 \%$ from family members and friends who have migrated to other areas.

Discussions with the community revealed that most of the weather forecasts are not accurate and some of the cell phone text messages are not authentic. One community leader said that sometimes they are told that a flood will occur, but they would spend the whole season without floods. As a result

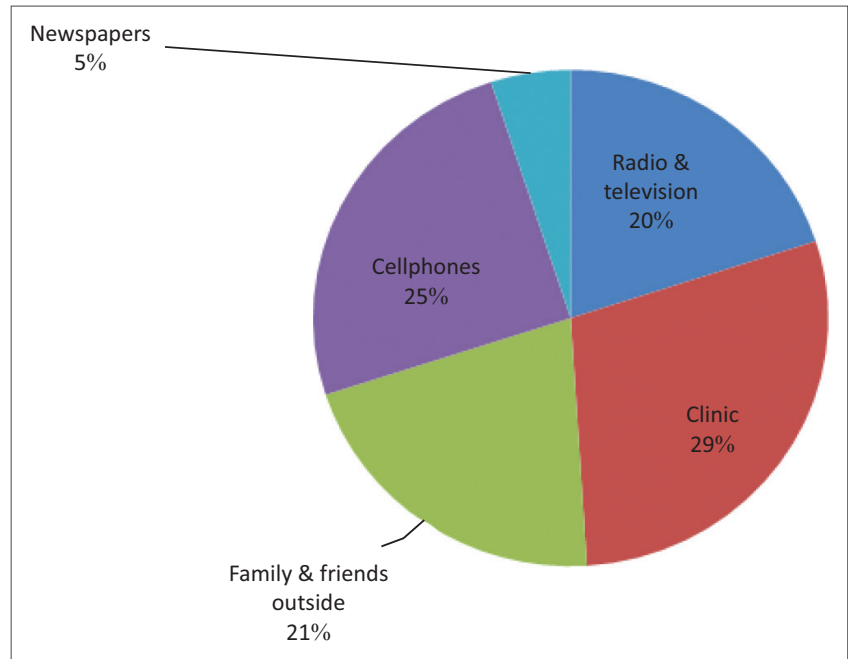

Source: Authors' own construction

FIGURE 3: Sources of early-warning information.

people do not rely on scientific weather forecasts; the greater majority of the population now opt for community flood prediction. Some of the traditional early warnings include observation of wind patterns, intensity of rainfall and the level of water in flowing rivers. Easterly winds indicate an imminent storm which results in serious flooding. Torrential rainfall for more than four hours also means serious flooding and the need to move to higher ground.

Tree markings on trees in the Hoya and Nzou-Mvunda rivers are used to measure the level of water in the flowing rivers. The method of using tree markings is still being developed, as previous experiences have given the community members very little lead time. Although there is a surveillance system to monitor the weather and give flood warnings to the community, one key informant indicated that the system is not reliable. He revealed that the fact that the system is monitored from South Africa and manned by Zimbabwe National Water Authority means there is no direct communication to the community, rendering the system less effective.

Ineffective and untimely communication has also affected the reliability of the system. This means that even if correct predictions are made, community members do not take heed. For instance, in 2012 some buildings were destroyed by the storm and people lost their belongings due to inaction after an on-the-spot prediction. Malene, Debnarayan and Ulla (2010) argue that warning information in disaster management is a vital tool, because it can minimise the loss of lives and infrastructure, as well as environmental and economic damage to disaster-prone communities. This can only be realised where there are effective and efficient early-warning systems (United Nations Development Programme 1994).

\section{Failure to interpret climatic data}

It emerged from the study that although the community is facing drought and flood hazards, most people had few skills to interpret climatic data. About $98 \%$ of the respondents stated that they had never received training on key weather aspects 
like climate change, terminology used, its effects as well as ways in which its effects can be reduced. As a result, one may point out that the local people lack the relevant knowledge and skills needed to determine the choice of coping strategies to adopt in the community. Malene et al. (2010) underscore the need to educate the vulnerable communities about the hazards they face, as well as training them on coping strategies to reduce losses when hazards strike.

\section{Lack of health education}

The researchers found that apart from reducing the impacts of floods on livelihoods, the community has to address the health problems posed by floods, such as malaria and cholera. The community is using both traditional and modern methods to treat and prevent the epidemics. Most respondents (41\%) take red pepper when they suspect malaria, even when not tested. About $28 \%$ said that they use a sugar and salt solution when someone is affected by cholera, indicating that the majority lack the knowledge of the importance of this health practice. However, from interviews and FGDs 31\% revealed that although they are using both traditional and modern methods, more children are dying of these epidemics than the floods themselves. Further consultations also revealed that most people die because they do not know what to do in times of crisis, and can take a long time to seek medical treatment. The behaviour of not knowing what to do during times of crisis is consistent with the findings of Few (2005) in Vietnam, and can be attributed to low levels of health education.

\section{Lack of local investment}

As long as poverty levels are not addressed, the limited capital to create employment for the community works against efforts to reduce the natural hazards. Investment would improve infrastructure, improve resource accessibility and promote affordable quality education and training and information dissemination within the area and the nation as a whole.

\section{Land degradation and deforestation}

Consultations with the community leaders revealed that most of the floods that occur in the area are due to the siltation of rivers causing backflow. Apart from stream bank cultivation, people clear land along the streams. This continuous cutting down of trees without effective community-level initiatives to replace them may lead to land degradation, thereby compromising the ability of the future generations to meet their own needs. According to Reed (1997), deforestation and removal of root systems increases run-off. Subsequent erosion causes sedimentation in river channels, which decreases their capacity. The stream bank cultivation activities in the area contribute to the change in the river course. Taking this into consideration, the community is increasing its vulnerability to floods in a bid to maintain food security.

\section{Unsafe conditions}

Several unsafe conditions as a result of dynamic pressures were identified, and these are discussed below.

\section{Fragile physical environment}

It emerged from the study that as a result of earlier identified root causes and dynamic pressures, the community's vulnerabilities are channelled into unsafe conditions. During field visits the researchers observed that the majority of settlements were concentrated along the Hoya and NzouMvunda rivers, in the flood plain, including their critical facilities like Chadereka Primary School, which is supposed to be used as a safe evacuation place.

In an interview as to why they were living in fragile environments, $87 \%$ of the respondents mentioned that they were lured by the wet, fertile soils there, and the location gave them opportunity to grow mudzedze, the only meaningful venture with higher returns in a fight against drought, as the majority had no other sources of income. This leads one to believing that the problem in this floodprone area is not floods, but the poverty which forces them to live in a fragile physical location that is in the path of water, and hence suffering flood disasters. This is in line with Wisner et al.'s (2004) argument that poor people have few livelihood options, and their coping strategies often put them at high risk of disasters.

\section{Fragile local economy}

The fragile local economy is characterised by livestock production and stream bank cultivation, as discussed below.

Livestock production: The 40 respondents indicated that they engage in livestock production so as to diversify their livelihoods. They mainly keep cattle, goats and poultry (Table 3). This sustainable practice cushions them during crop losses caused by droughts and floods.

Table 3 indicates that the majority (46\%) have 6-10 cattle, 25\% have $1-5$, only $6 \%$ have $16-20$, and very few have none or more than 20. Goats, sheep and poultry also form part of the livestock reared in the area. Donkeys are not very common in the area; $86 \%$ of respondents noted that they do not keep them because of the low value attached to them. Discussions with household heads and community leaders indicate that the livestock act as a safety net in times of crisis; however, community leaders are worried because most households are selling livestock at very low prices and some even barter them for cereals.

Del Ninno et al. (2001) acknowledge that communities dispose of their assets as a coping strategy when exposed to floods. In this study about $70 \%$ of the respondents had sold assets during the post-disaster period, the main disposable assets including

\begin{tabular}{|c|c|c|c|c|c|c|c|}
\hline $\begin{array}{l}\text { Type of } \\
\text { Livestock }\end{array}$ & None & $1-5$ & $6-10$ & $11-15$ & $16-20$ & $20+$ & Total \\
\hline Cattle & 5 & 25 & 46 & 15 & 6 & 3 & 100 \\
\hline Goats & 3 & 19 & 35 & 37 & 14 & 2 & 100 \\
\hline Donkeys & 86 & 14 & 0 & 0 & 0 & 0 & 100 \\
\hline Sheep & 72 & 12 & 6 & 0 & 0 & 0 & 100 \\
\hline Poultry & 0 & 10 & 35 & 38 & 12 & 5 & 100 \\
\hline
\end{tabular}


chickens, cattle and goats. About $90 \%$ of the respondents had sold chickens, half had sold goats and about 35\% had sold cattle. Cows were considered for selling first, since lesser value is attached to them as compared to oxen which have higher value due to their ability to provide draught power. During the lean season one beast can be traded for a bag of maize, which normally averages $\$ 15$, but doubles or trebles depending on availability. Chickens and goats are the most common assets to be sold because almost every household had either chickens or goats. Whilst decapitalisation of resources is one challenge the community is facing, the same livestock that the community fall back on during droughts are being put at risk by the unsustainable practices, for example, stream bank cultivation which promotes flooding.

Stream bank cultivation: It was observed in the study that $87 \%$ of the respondents were practising farming along the river banks in a bid to fight against hunger due to drought. Respondents highlighted that the floodplains offer favourable conditions for human settlement, economic development and assets for sustainable livelihood support. After a flood, the community is given seeds under market gardening and agricultural schemes by the Government and NGOs, and these crops are grown along the flood plain (Figure 4), which gives them higher yields than the normal crop production.

Respondents highlighted that they prefer to take the risk of living in the disaster-prone area and have enough food to feed their families. Wisner et al. (2004) echo similar sentiments in their argument that poor people often adopt harmful coping measures as their immediate desire is to satisfy physiological
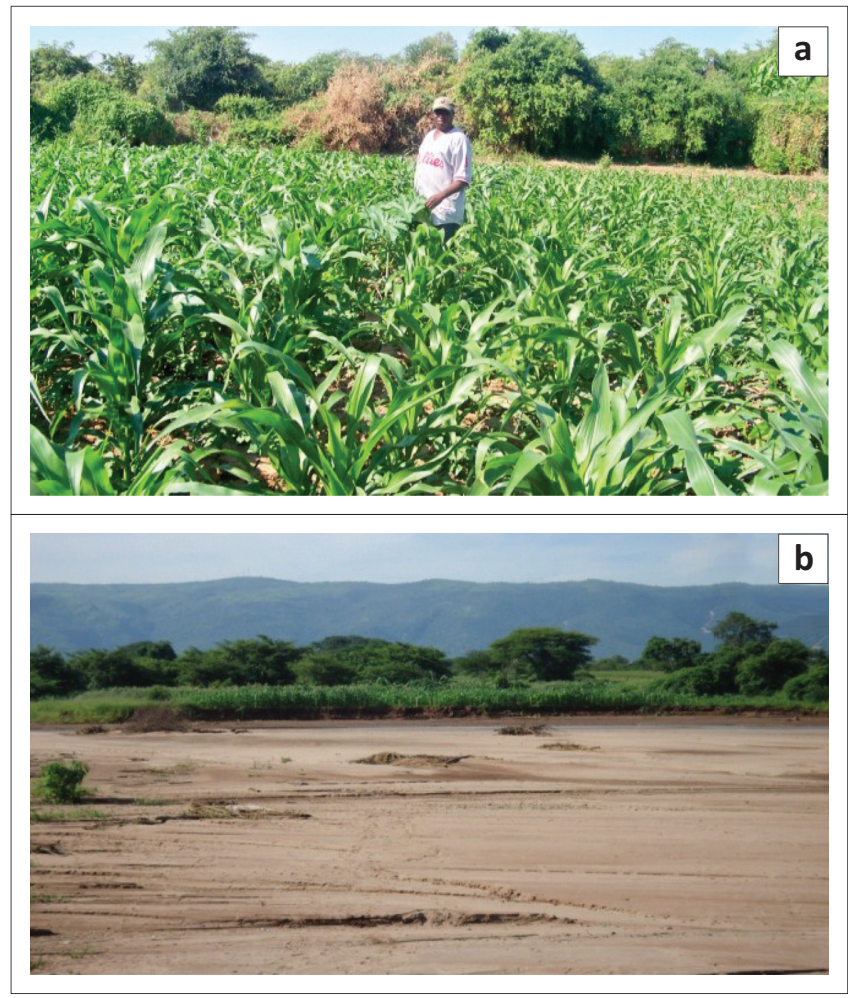

Source: ( $\mathrm{a}$ and $\mathrm{b})$ taken by $\mathrm{C}$. Mudavanhu

FIGURE 4: (a, b) Mudzedze (maize crop) thriving along the silted river. needs. This is also supported by Bang (2008), whose study on social vulnerability to and risk perception of natural hazards in Cameroon two decades after the Lake Nyos gas disaster noted that income-related livelihood issues are the most important factors to be considered by a community before it can take or make any subsequent migration or relocation decisions. The problem is often not simply the lack of awareness, but rather assessment of local risks based on experience that underestimates the impact of accumulating risk (Few 2005). Whilst the promotion of food security is a welcome intervention, it seems to be exacerbating the vulnerability of the community, since they practice stream bank cultivation which results in river siltation (Figure 4), advancing the possibility of floods.

\section{Inaccessibility due to poor infrastructure}

It was noted during the study that the community is inaccessible during the rainy season due to poor road infrastructure. The area has no standard bridge, making it inaccessible by buses and cars. However, in a bid to reduce the challenges the local people have constructed a footbridge (Figure 5) using local resources with the help of World Vision Zimbabwe.

Even though the footbridge has helped people to access schools, concerns were raised that the area was still inaccessible by buses and cars, forcing people to travel long distances to get transport to major services such as hospitals. Also, $67 \%$ of respondents stated that they had sometimes failed to get help during floods as the area would be inaccessible. Poverty and lack of financial resources were cited as the major constraints hindering construction of a standard bridge.

Whilst schools are considered safe havens for the local community during flooding, they are not safe at all. Key informant interviews pointed out that the community lacked resources to construct strong and sturdy school buildings which can resist adverse weather conditions. For instance, it was revealed that the nearby Chadereka Primary School had its roof blown off during the 2012 storm. Lack of access to economic power by the Chadereka community hinders adherence to recommended building standards.

Whilst the NGOs' moves to restore the damaged schools are welcome, their actions only increase the vulnerability of the community by bringing the false hope of having a

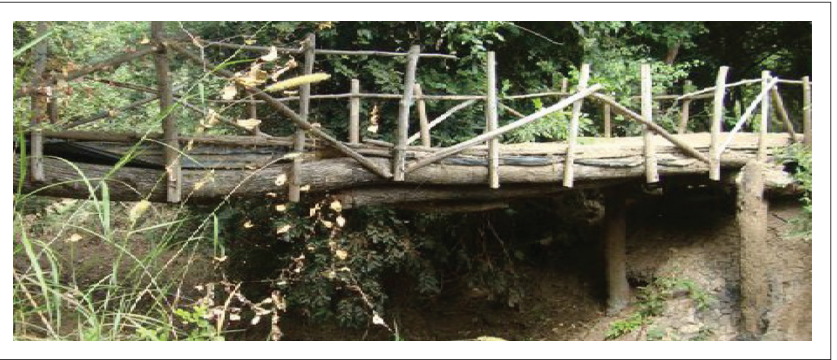

Source: Taken by C. Mudavanhu

FIGURE 5: Footbridge constructed by local people. 
safe haven in their area during flooding. The community cohesion shown during rehabilitation of the primary school is nevertheless a capacity that the community possesses which could be harnessed if resources were abundant.

Similarly, it was noted that most of the houses in the area were built using cheap poles and mud material, and this makes people highly vulnerable to infrastructural damage and property loss. About $89 \%$ of the respondents indicated that although they are aware of the risk, they could not do much about their plight as they had no means to build floodresistant buildings. Therefore people evacuate the area during the flooding period and come back after the floods. They have also adopted house construction techniques such as deepening their foundations and raised doorsteps, and most of their houses face the direction opposite to where the flooding water normally flows from, to block water from entering the house as part of flood-coping mechanisms. However, in a study by Gaston (2006) on flood risk management in Tanzania it was reported that flood victims always move back to their damaged houses, and their safety remained a concern because the structural stability of the houses is also unknown.

\section{Inadequate disaster preparedness}

Despite numerous occurrences of floods, epidemics and droughts, this study revealed that there is a lack of disasterpreparedness planning. Sutton and Tierney (2006) note that preparedness efforts ensure that the resources necessary for effective response in the event of a disaster are in place, and that those faced with the predicament know how to use those resources. This research indicated that $35 \%$ of respondents received external aid during a disaster. Most of the support was from Government disaster management programmes and NGOs, whilst $20 \%$ of the respondents were assisted by relatives and friends, churches and well-wishers. Most received donations in the form of foodstuffs, blankets, pots and cups.

Despite receiving relief support, the majority of respondents $(45 \%)$ did not receive any external support during the flood period, and respondents felt that the aid was handled and distributed corruptly. The aid was also said not to be enough, since the majority did not benefit. However, respondents felt that they could not survive on their own without external support, which in turn could mean that the coping strategies are not sustainable. Despite assistance from donor agencies, findings revealed that the support is emergency relief only, with no meaningful investment in recovery and resilience in the community. Thus a reactive stance is taken by Government and NGOs, as these move in response to hazardous effects rather than to prevent the progression of vulnerability.

Respondents confirmed that a number of risk assessments had been carried out in the study area; however, there has been no feedback to the community on those assessments. It was nevertheless gathered that the projects that are implemented in the community by NGOs are done after risk assessments. Lack of feedback on risk assessments shows that the community is not fully involved in the whole process.
Newport and Jawaha (2003) argue that participation has the ability to make local communities feel more confident in their capabilities to act in the event of a disaster, thus increasing their resilience. In this study the partial involvement of the Chadereka community might only drive the community towards more vulnerability rather than resilience, as they lack ownership of the assessments and subsequent programmes.

The lack of flood, health and drought insurance also contributes to the progression of vulnerability in the Chadereka community. Insurance allows risk to be spread over a larger community and also allows the cost to be spread over a long period of time through premium payments. Those less affected by a disaster also bear part of the cost, reducing the burden of those hardest hit. As in the case of New Carolina in the United States of America, highlighted by Hyndman and Hyndman (2011), houses built in areas of high probability of flooding are not insured, and the high insurance premiums charged in flood-prone areas deter development there. The same could be done in Muzarabani.

Whilst drought insurance is offered to Zimbabwean commercial farmers, this could also be introduced for these subsistence farmers on livestock raised and crops grown on designated land. Although insurance does not reduce the physical impact caused by disasters, it gives certainty of financial recovery, thus reducing stress in the aftermath of a disaster (Bull 1994). If individuals in Chadereka had insurance, they would be enabled to replace material damage to houses quickly, as well as replacing crops and livestock. However, affordable premiums have to be negotiated between community members and insurers, since high premiums would hinder uptake by eligible households.

As denoted by the PAR approach, disasters occur when natural hazards affect vulnerable people. According to Wisner et al. (2004), vulnerability is defined within three progressive levels (Figure 6), starting from root causes which build dynamic pressures on the communities, eventually leading to unsafe conditions which, if impacted upon by a hazard (in this case floods, epidemics or droughts) results in a disaster. This progression of vulnerability builds up pressures on communities that can be released by taking disaster risk-reduction measures to reduce vulnerability all along the causal chain. This thinking thus builds the basis for the recommendations made in this article. Human livelihoods are often earned in locations that combine opportunities with hazards. Figure 6 shows a summary of prevailing conditions in Muzarabani presented by the respondents.

\section{Conclusion and recommendations}

A number of conclusions are drawn from this study, and recommendations provided. It is concluded that Muzarabani is progressing towards vulnerability to natural hazards, in spite of disaster risk reduction being put in place. Poverty, lack of education, limited access to resources and cultural beliefs force the community to adopt maladaptation, which makes the community susceptible to droughts and floods. 


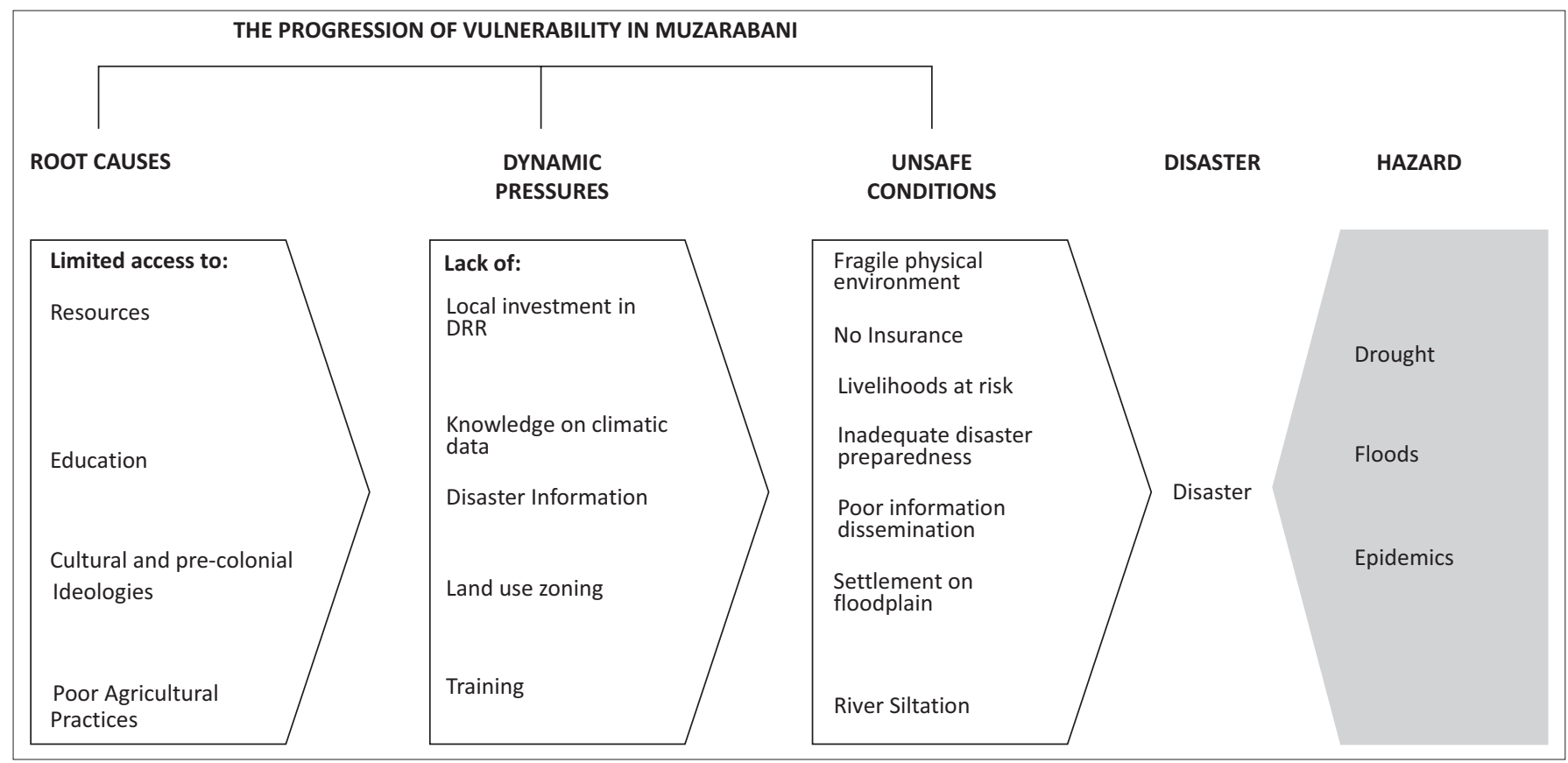

Source: Adapted from Wisner, B., Blaikie, P., Cannon, T. \& Davis, I., 2004, At Risk: Natural Hazards, People's Vulnerability and Disasters, 2nd edn., Routledge, New York FIGURE 6: Pressure and release model depicting the progression of vulnerability in Muzarabani.

The major problem in the area is not floods, but settlement in a flood-prone zone.

The coping measures undertaken in Muzarabani make the community progress to vulnerability, and thusdrastic measures are needed to reverse the scenario so that it progresses to safety. Maladaptation strategies provide short-term benefits, with long-term repercussions. Challenges presented by floods, drought and epidemics force the community to adopt such measures as stream bank cultivation, cutting down of trees along the stream bank, building a footbridge, settlement on the flood plain and livestock production. Whilst these strategies seem to offer solutions, the issue of sustainability is questionable, because some of them tend to promote the disaster risk accumulation process. Some of the coping strategies adopted are destroying the environment, thereby prejudicing the present and future generations.

On the basis of these findings it is recommended that there is a need to address the root causes in order to reverse the dynamic pressures and eliminate the problems manifesting as unsafe conditions. Addressing root causes will reverse settlement on the flood plain, strengthen the local economy and improve public actions. Efforts should be channelled to programmes that fight poverty, empower the community through education, and create employment, affording the community access to credit and local investment. Access to financial resources and education tend to deter people from cultivating crops along stream banks, as they will have other sources of income.

Baiyegunhi and Fraser (2010) are in agreement with this view, arguing that education reduces poverty and increases livelihood opportunities. There is a need to improve availability of and access to health education through training, monitoring and evaluation of more village health workers and ward health coordinators. The research also recommends that there should be disaster-preparedness planning to redress the challenges of unequal distribution of aid during emergencies. Kent (1994) points out that disasterpreparedness planning is crucial, as it helps in providing due aid assistance to disaster victims. Such moves will help the community progress to safety, and hence reduce disaster risk.

\section{Acknowledgements}

\section{Competing interests}

The authors declare that they have no financial or personal relationship(s) that may have inappropriately influenced them in writing this article.

\section{Authors' contributions}

S.N-P. (Bindura University of Science Education) was involved in data collection, analysis, compilation and write up, and C.M. (Bindura University of Science Education) and B.M. (Bindura University of Science Education) were involved in data collection, analysis and proofreading.

\section{References}

Bang, H.N., 2008, 'Social vulnerability and risk perception to natural hazards in Cameroon two decades after the lake Nyos gas disaster: What future prospect for the displaced disaster victims?', Presentation during the 2008 Summer Academy at the United Nations University UNU EHS in Germany, viewed 13 May 2013, from http://www.ehs.unu.edu/file/get/3941

Baiyegunhi, L.J.C. \& Fraser, G.C.G., 2010, 'Determinants of household poverty dynamics in rural regions of the Eastern Cape Province, South Africa', poster presented at the Joint 3rd African Association of Agricultural Economists (AAAE) and 48th Agricultural Economists Association of South Africa (AEASA) Conference, Cape Town, South Africa, September 19-23, 2010, Research Gate, viewed 04 June 2013, from http://www.researchgate.net/go.To.html?u=http $\% 3 \mathrm{~A} \% 2 \mathrm{~F} \% 2 \mathrm{Fagecon}$ search.umn.edu $\% 2$ Fbitstream $\% 2$ F $97078 \% 2$ F2 $\% 2$ F $63 . \% 2520$ Poverty $\% 2520$ dyna mics\%2520in\%2520South\%2520Africa.pdf\&ev=pub_ext_doc_dlext

Bull, R., 1994, Disaster Economics, 2nd edn., United Nations Development Program, New York. 
Chikoto, G.L., 2004, Zimbabwe's emergency management systems, Disaster Management class project, Georgia State University, Atlanta, Georgia.

Creswell, J.W. \& Plano, C.V.L., 2011, Designing and conducting mixed-methods research, 2nd edn., Thousand Oaks, California.

Del Ninno, C., Dorosh, P.A., Smith, L.C. \& Roy, D.K., 2001, The 1998 floods in Bangladesh: Disaster impacts, household coping strategies, response, viewed 13 March 2012, from http://www.ifpri.org/sites/default/files/publications/rr122.pdf

Few, R., 2005, Health and flood Risk: A strategic assessment of adaptation processes and policies, Tyndall Centre for Climatic Change Research Technical Report 17 Project T3, 31, University of East Anglia, viewed 28 December 2012, from http:// ceh.ersourcehub.ssrc.org/health-and-flood-risk-assessment-of-adaptationprocesses-and-policies/resource_view

Gaston, A.S., 2006, Advocating the adoption of challenging, modern approaches to disaster risk reduction to facilitate the sustainable development of vulnerable communities, Tanzania, Unpublished report, ProVention Research and Action communities, Tanz

Gwimbi, P., 2009, 'Linking rural community livelihoods to resilience building in flood risk reduction in Zimbabwe', Journal of Disaster Risk Studies 2(1), 71-80, viewed 13 March 2012, from http://web.ndmc.gov.za/docs/publications/Jamba. pdf\#page $=82$

Hansford, B., Dellor, S. \& MacPherson, S., 2007, Disaster risk reduction, Tearfund, Teddington.

Hyndman, D. \& Hyndman, D., 2011, Natural hazards and disasters, 3rd edn, Brooks/ Cole, Michigan.

Kent, R., 1994, Disaster Preparedness, 2nd edn., United Nations Development Program, Geneva.

International Federation of Red Cross and Red Crescent Societies, 2007, Zimbabwe: Muzarabani floods, viewed 13 March 2012, from http://www.ifrc.org/docs/ appeals/07/MDRZM002a.pdf

International Federation of Red Cross and Red Crescent Societies, 2008, Early warning early action, International Federation of Red Cross and Red Crescent Societies, Geneva.
Madamombe, E.K., 2004, Zimbabwe: Flood management practices - selected flood prone areas Zambezi Basin, Zimbabwe National Water Authority, Harare.

Malene, F., Debnarayan, B. \& Ulla, D., 2010, Establishing community based early warning system: Practitioner's handbook, Mercy Corps, Senepa Chowk.

Newport, J.K. \& Jawaha, G.G.P., 2003, 'Community participation and public awareness in disaster mitigation', Disaster Prevention and Management 12(1), 33-36. http:// dx.doi.org/10.1108/09653560310463838

Reed, S., 1997, Introduction to Hazards, 3rd edn., United Nations Development Program, Geneva.

Robson, C., 1993, Real world research, Blackwell Publishers, Massachusetts.

Sutton, J. \& Tierney, K., 2006, Preparedness: Concepts, guidance and research viewed 10 March 2013, from http://www.fritzinstitute.org/PDFs/WhitePaper/ DisasterPreparedness-Concepts.pdf

Teddlie, C. \& Yu, F., 2007, 'Mixed methods sampling: A typology with examples', Journal of Mixed Methods Research 1(1), 77-100. http://dx.doi. org/10.1177/2345678906292430

United Nations Development Programme, 1992, An Overview of Disaster Management, 2nd edn., United Nations Development Programme, Geneva.

United Nations Development Programme, 1994, Disaster Preparedness, 2nd edn., United Nations Development Programme, Geneva.

Walden, V.M., O'Reilly, M. \& Yetter, M., 2007, Humanitarian programmes and HIV and AIDS: A practical approach to mainstreaming, Oxfam, New York.

Wamukonya, N. \& Rukato, H., 2001, 'Climate Change Implications for Southern Africa: A Gender Perspective', International Network on Gender an Sustainable Energy, viewed 14 May 2013, from http://www.energia.org

Wisner, B., Blaikie, P., Cannon, T. \& Davis, I., 2004, At Risk: Natural Hazards, People's Vulnerability and Disasters, 2nd edn., Routledge, New York.

Zimbabwe National Statistics Agency, 2013, Poverty and poverty datum line analysis in Zimbabwe, Zimbabwe National Statistics Agency, Harare. 